\title{
Influence of Abrams M1A1 Main Battle Tank Disturbance on Tallgrass Prairie Plant Community Structure
}

\author{
Peggy S. Althoff, ${ }^{1}$ Mary Beth Kirkham, ${ }^{2}$ Timothy C. Todd, ${ }^{3}$ Stephen J. Thien, ${ }^{2}$ and Philip S. Gipson ${ }^{4}$ \\ Authors are ${ }^{1}$ Graduate Research Assistant and ${ }^{2}$ Professors, Department of Agronomy, Kansas State University, Manhattan, KS 66506, USA; ${ }^{3}$ Instructor, \\ Department of Plant Pathology, Kansas State University, Manhattan, KS 66506, USA; and ${ }^{4}$ Chairperson and Professor of Natural Resource Management, \\ Texas Tech University, Box 42125, Lubbock, TX 79409-2125, USA.
}

\begin{abstract}
The Department of Defense's Range and Training Land Assessment program provides information and recommendations to range managers regarding the condition of training lands. This information is used to assist in scheduling training areas and in monitoring the effectiveness of rehabilitation projects. Fort Riley Military Installation is a major training reservation located in the Flint Hills of northeastern Kansas, within the tallgrass prairie ecosystem. A randomized complete block design composed of three treatments (M1A1 Abrams tank traffic during wet and dry soil conditions, and a nontrafficked control) with three replications was established in each of two soil types, a silty clay loam and a silt loam soil, on Fort Riley in 2003. Disturbance was created by driving the tank for five circuits in a figure-eight pattern during either during wet or dry soil conditions. Two additional experimental treatments were added during the study: five additional tank passes on one-half of each figure eight in 2004 and burning in 2006. Two areas, a curve and straightaway, within each traffic intensity (and later, burn treatment) subplot were designated for sampling. Aboveground biomass, species composition, and ground cover were measured during each growing season. Recovery of grass and total aboveground biomass in silty clay loam soil was delayed for curve areas and following disturbance in wet soil conditions, respectively. Species composition and ground cover continued to exhibit significant disturbance effects in 2007, with greatest damage observed for repeated traffic under wet soil conditions. Fire effects on vegetation were variable and generally greater for undisturbed control plots than for disturbed areas. The tallgrass prairie typically is considered to be among the most resilient of military training lands, but our research suggests that resiliency is dependent upon soil type and training conditions, and may require longer periods of recovery than previously thought.
\end{abstract}

\section{Resumen}

El programa de entrenamiento y valoración de Tierras del Departamento de Defensa provee información y recomendaciones a los manejadores de pastizales sobre la condición de las tierras de entrenamiento. Esta información se utiliza en la selección de áreas de entrenamiento así como para el monitoreo de la efectividad de los proyectos de rehabilitación. Las instalaciones militares del Fuerte Riley es una importante reservación de entrenamiento localizada en Flint Hills al noreste de Kansas, dentro de los ecosistemas de praderas de pastos altos. Un diseño de bloques al azar, compuesto de tres tratamientos (Tráfico de tanques Abrams M1A1 bajo condiciones de suelo húmedo y seco, y un área control sin tráfico), con tres repeticiones se establecieron en dos sitios con diferente tipo de suelo, un suelo limo-arcilloso y un suelo limoso en el Fuerte Riley en 2003. El disturbio fue creado mediante la conducción del tanque en cinco circuitos en forma de ocho durante condiciones de suelo húmedo o suelo seco. Se incluyeron otros dos tratamientos experimentales durante el estudio: Cinco pasadas adicionales del tanque en cada mitad de la figura de ocho en 2004, y quema en 2006. Se diseñaron subparcelas para muestreo en dos áreas, una curva y una línea recta en cada intensidad de tráfico (y después, tratamiento de quema). En cada estación de crecimiento se midió producción de biomasa, composición de especies y cobertura. La recuperación del pasto y la biomasa total en el suelo limoarcilloso fue más lenta después del disturbio en las áreas curvas y bajo condiciones de suelo húmedo, respectivamente. La composición de especies y la cobertura continuó mostrando un efecto significativo de disturbio en 2007, con un mayor daño observado con el tráfico repetido bajo condiciones de suelo húmedo. Los efectos del fuego sobre la vegetación fueron variables pero generalmente mayores en las parcelas del control sin disturbio que en las áreas con disturbio. Los pastizales con pastos altos son comúnmente considerados entre las tierras de una recuperación masa rápida después del entrenamiento militar, pero nuestra investigación sugiere que esa recuperación depende del tipo de suelo y de las condiciones de entrenamiento, y posiblemente puedan necesitar mayores periodos de recuperación de lo que se pensaba anteriormente.

Key Words: military impacts, net primary production, resilience, species composition

Contribution no. 09-067-J from the Kansas Agricultural Experiment Station, Manhattan. Research was funded by the US Army Military Installation, Integrated Training Area Management Program.

Correspondence: Timothy C. Todd, Dept of Plant Pathology, Kansas State University, Manhattan, KS 66506, USA. Email: nema@ksu.edu

Manuscript received 3 March 2009; manuscript accepted 28 June 2009

\section{INTRODUCTION}

The environmental impacts of military vehicle use have been reviewed by Anderson et al. (2005a). Effects on vegetation, in particular, can be severe during intensive military training, resulting in notable changes to the plant community. Dense 
stand establishment (i.e., tillering) and the ability to produce rhizomes are two characteristics of grasses associated with recovery following vehicle disturbance (Palazzo et al. 2005), and for this reason, the tallgrass prairie, a community dominated by deep-rooted perennial rhizomatous grasses, may be relatively more resilient when compared to other military lands. Gunderson (2000) has reviewed the varied definitions of resilience in the literature, which include the magnitude of disturbance that an ecosystem can withstand without changing self-organized processes and structures and the time required for a system to return to an equilibrium or steady-state state following perturbation. Holling (1973) originally introduced the term, defining resilience as the amount of disturbance that a system can absorb without changing state. In the tallgrass prairie ecosystem, plant community structure appears to be an important measure of resilience, with the dominant native $\mathrm{C}_{4}$ grasses providing greater stability and more rapid recovery than introduced $\mathrm{C}_{3}$ grasses in the presence of military traffic disturbance (Dickson et al. 2008).

Several studies have examined the resilience of the tallgrass prairie ecosystem to training activities on the Fort Riley Military Installation, a major training reservation located in the Flint Hills of northeastern Kansas, with $70 \%$ of its 40434 ha used for mechanized maneuvers. In a preliminary assessment of training sites on Fort Riley, plant biomass showed no discernible trends related to training activities, with values well within the range observed for native tallgrass prairie (Schaeffer et al. 1990). Species composition, however, was affected, with the abundance of the dominant grass big bluestem (Andropogon gerardii) greatly reduced compared to the native site. Increased bare soil, reduced total plant cover, and compositional shifts in plant communities in favor of annual and introduced species over perennial and native species were reported for areas of high training use by Quist et al. (2003). Subsequent monitoring showed little change in plant species diversity in training areas, but invasive species and bare ground both increased over time in areas of concentrated, mechanized training (Althoff et al. 2006). Traffic intensity is a critical factor determining vegetation recovery patterns, with desirable species declining as traffic intensity increases (Palazzo et al. 2005; Dickson et al. 2008). Anderson et al. (2005b) developed a model predicting decreased ground and aerial vegetative cover associated with increased training intensity.

Land maintenance on military training sites is currently guided by regulations set forth by the Integrated Training Area Management (ITAM) program, which outlines procedures for achieving sustainable use of training lands (Army Regulation 350-4 1988). A key component of this program, Range and Training Land Assessment, provides information and makes recommendations to range control managers concerning the condition of training lands, which are used to assist scheduling of training areas and monitoring of the effectiveness of rehabilitation projects (US Army Environmental Center 2006). Fort Riley started implementing portions of the assessment protocol under the Land Condition Trend Analysis (LCTA) program by monitoring trends in plant communities related to military vehicle traffic patterns during 1994-2001 (Althoff et al. 2006). Assessment of soil quality indices, including physical, chemical, and biological properties, began in 2002 (Althoff 2005; Althoff and Thien 2005; Althoff et al. 2007).

A replicated small-plot study of tracked vehicle disturbance on tallgrass prairie soils and plant communities was initiated on Fort Riley in 2003. The objectives of this study were to evaluate rates of recovery of a suite of plant and soil-quality indicators over a range of disturbances, soil types, and environmental conditions. Results from the first $2 \mathrm{yr}$ are reported in Althoff (2005) and Althoff and Thien (2005). This manuscript reports longer-term (2003-2007) trends in plant community responses following tank disturbance.

\section{MATERIALS AND METHODS}

\section{Site Description}

Research was conducted at Fort Riley Military Installation, an Army base in operation since 1853, located in Clay, Geary, and Riley counties in the Flint Hills of northeastern Kansas $\left(39^{\circ} 15^{\prime} \mathrm{N}, 96^{\circ} 50^{\prime} \mathrm{W}\right)$. The installation, located in a mesic, tallgrass-prairie ecosystem, uses 29542 ha (70 926 acres) of its 40434 ha (100656 acres) for maneuver training. The Flint Hills grasslands encompass more than 1.6 million ha, covering much of eastern Kansas from near the Kansas-Nebraska border south into northeastern Oklahoma, and contain the largest remaining area of tallgrass prairie in North America (Knapp and Seastedt 1998). Hot summers and cold, dry winters characterize the climate. Mean monthly temperatures range from $-2.7^{\circ} \mathrm{C}$ in January to $26.6^{\circ} \mathrm{C}$ in July. Annual precipitation averages $83.5 \mathrm{~cm}$, with $75 \%$ of precipitation occurring during the growing season (Hayden 1998). Three major vegetative communities are found on Fort Riley: grasslands (ca. 32200 ha), shrublands (ca. 6000 ha), and woodlands (ca. $1600 \mathrm{ha}$ ). The soil at the study plots was classified as a Wymore series consisting of very deep, moderately drained, slowly or very slowly permeable soils that formed in loess (US Department of Agriculture 1975). This soil series is found on most of the Fort's training area. Wymore soils are classified as fine, smectic, mesic Aquertic Argiudolls.

\section{Experimental Treatments}

Nine $20 \times 40 \mathrm{~m}$ plots representing three treatments (a nontrafficked control, tank traffic during wet soil conditions, and tank traffic during dry soil conditions) and three replications were established in a randomized complete block design in each of two soil types, a silty clay loam and a silt loam, in 2003 (Althoff and Thien 2005). An Abrams M1A1 main battle tank was used to create disturbance by driving five circuits in a figureeight pattern during wet ( $30 \%$ gravimetric soil water content) and dry ( $8 \%$ gravimetric soil water content) soil conditions. The M1A1 weighs $57.2 \mathrm{t}$ with a ground pressure of $0.00626 \mathrm{t} \cdot \mathrm{cm}^{-2}$ $\left(13.8\right.$ pounds $\cdot$ inch $\left.^{-2}\right)$. The tracks are approximately $63.5 \mathrm{~cm}$ (25 inches) wide and $4.57 \mathrm{~m}$ (15 feet) long. This tank has a maximum cross country speed of $48 \mathrm{~km} \cdot \mathrm{h}^{-1}\left(30 \mathrm{miles} \cdot \mathrm{h}^{-1}\right)$, but speed was maintained at approximately $8 \mathrm{~km} \cdot \mathrm{h}^{-1}(5$ miles $\cdot \mathrm{h}^{-1}$ ) during the disturbance treatment.

In 2004, one-half of each of the previously disturbed plots received five additional tank passes during wet or dry conditions similar to 2003. On a randomly selected half of the original figure eight, five additional passes were made with 

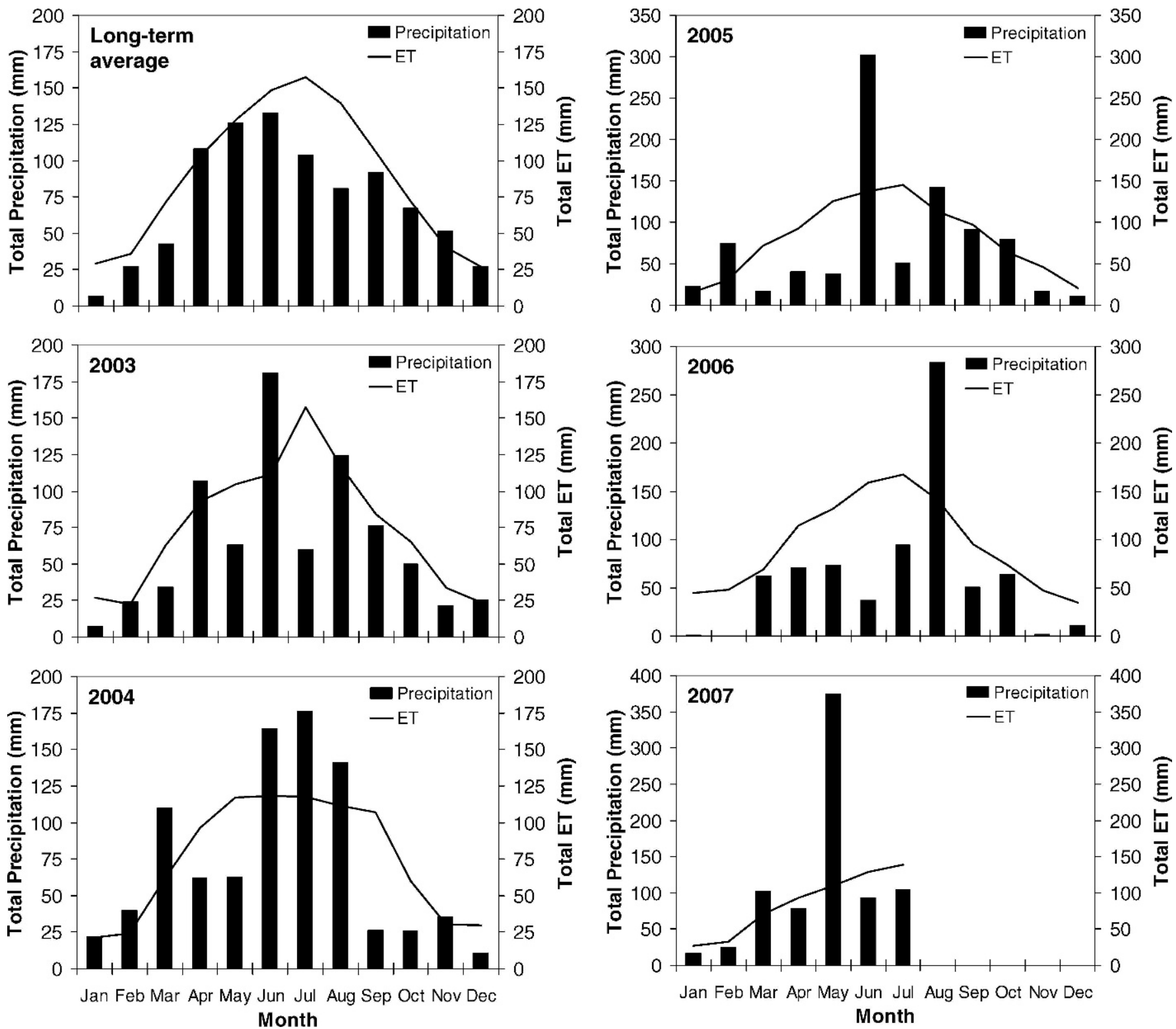

Figure 1. Mean monthly precipitation and evapotranspiration (ET) values for Fort Riley, Kansas based on long-term records and for the years 20032007.

an M1A1 tank, producing an S-shaped pattern (Althoff 2005). The second year of treatments allowed comparison of different levels of traffic intensity (one-time traffic event of five passes vs. repeated traffic with a total of 10 passes). Two areas, a curve and straightaway, within each traffic intensity subplot were designated for sampling in 2005. Data from the first and second years of disturbance are reported in Althoff (2005) and Althoff and Thien (2005).

In April 2006, each whole plot was again split and a randomly selected half received a burn treatment. Curve and straightaway areas within each burn-intensity subplot were designated for sampling in 2006 and 2007.

\section{Field Sampling and Laboratory Methods}

Aboveground Biomass. Plant biomass samples were collected on 10 June 2004, 8 June 2005, 1 October 2006, and 2 July 2007 from curve and straightaway areas of the outside tank tracks of single and repeated traffic events using a $20 \times 50 \mathrm{~cm}$ sampling frame. Biomass samples also were collected from two randomly selected sites in nondisturbed control plots on each date. The target date of June was chosen for biomass sampling to ensure that both cool-season and warm-season species were represented and to minimize differences due to seasonality. Living plant biomass was clipped, sorted into grass or forb categories, dried $48 \mathrm{~h}$ at $40^{\circ} \mathrm{C}$, and weighed (Althoff 2005, 2007).

Step Point. Plant species composition and basal area were determined from transects comprised of 100 points for each figure eight (whole plot) with the use of the modified step-point technique (Evans and Love 1957). Points were collected from the outside tank track for disturbed plots and incorporated both curve and straightaway areas. Four 25-point transects were used for each nondisturbed control plot. Data were 
Table 1. Analysis of linear and quadratic trends in recovery of aboveground biomass for grasses, forbs, and total vegetation following disturbance by an Abrams M1A1 main battle tank. ${ }^{1}$

\begin{tabular}{|c|c|c|c|c|c|c|c|}
\hline \multirow[b]{3}{*}{ Effect $^{2}$} & \multirow[b]{3}{*}{ df } & \multicolumn{6}{|c|}{$F$ value } \\
\hline & & \multicolumn{3}{|c|}{ Silty clay loam soil } & \multicolumn{3}{|c|}{ Silt loam soil } \\
\hline & & Grass & Forb & Total & Grass & Forb & Total \\
\hline Treatment $(\mathrm{T})$ & 1,6 & 0.00 & 0.18 & 4.04 & 0.12 & 0.09 & 0.16 \\
\hline Traffic intensity (I) & 1,6 & 0.08 & 0.00 & 0.07 & 0.32 & 0.05 & 1.60 \\
\hline $\mathrm{T} \times \mathrm{I}$ & 1,6 & 0.01 & 0.00 & 0.71 & 0.15 & 0.14 & 0.04 \\
\hline Area $(A)$ & 1,8 & 0.01 & 1.54 & 2.36 & 0.49 & 1.98 & 0.04 \\
\hline $\mathrm{T} \times \mathrm{A}$ & 1,8 & 0.03 & 0.09 & 0.33 & 0.07 & 0.36 & 0.27 \\
\hline$I \times A$ & 1,8 & 1.45 & 0.00 & 0.03 & 0.02 & 0.78 & 0.05 \\
\hline $\mathrm{T} \times \mathrm{I} \times \mathrm{A}$ & 1,8 & 0.22 & 0.03 & 0.09 & 0.10 & 0.34 & 0.03 \\
\hline Linear trend $(\mathrm{Yr})$ & 1,76 & $76.90^{\star \star 3}$ & $13.62^{* *}$ & $34.79^{* *}$ & $81.36^{\star *}$ & $15.41^{* *}$ & $96.62^{* *}$ \\
\hline $\operatorname{Yr} \times A$ & 1,76 & $4.54^{\star}$ & NS & NS & NS & NS & NS \\
\hline Quadratic trend & 1,76 & NS & NS & $8.71^{* *}$ & NS & NS & NS \\
\hline
\end{tabular}

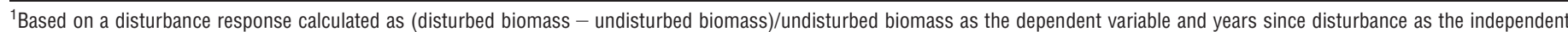
variable.

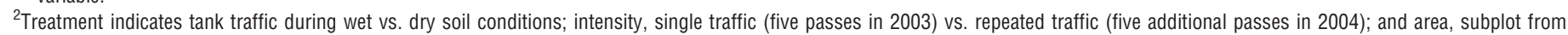
which sample was collected (curve vs. straightaway).

${ }^{3}$ Denotes significance at the $P \leq{ }^{\star} 0.05,{ }^{\star *} 0.01$ probability levels, respectively. NS indicates not significant.

recorded separately for the eight most abundant grass species (big bluestem, little bluestem [Schizachyrium scoparium], switchgrass [Panicum virgatum], indiangrass [Sorghastrum nutans], dropseed [Sporobolus asper], brome [Bromus spp.], prairie junegrass [Koeleria macrantha], and sedge [Carex spp.]) and the five most abundant forb species (heath aster [Aster ericoides], Illinois bundleflower [Desmanthus illinoensis], ragweed [Ambrosia spp.], goldenrod [Solidago spp.], and daisy fleabane [Erigeron strigosus]). All other species were grouped into "other grasses" or "other forb" categories. Percentage bare ground and litter cover also were estimated with this technique.

\section{Bare Ground Analysis With the Use of Aerial Photographs}

Field Procedure. High-quality digital images of plots were obtained with the use of a low-level aerial photography system (LLAPS) consisting of a remotely controlled aerial photography platform suspended below a 5.5-m (18-foot) helium-filled blimp tethered to and controlled by personnel (Kansas Cooperative Fish and Wildlife Research Unit) on the ground. A 5.0-megapixel Nikon digital camera was used in 2004, 2005, and 2006 and a 10-megapixel Sony DSC-R1 camera was used in 2007. Prior to conducting the aerial photography, highly visible white markers, $25 \times 25 \mathrm{~cm}$ in size, were placed within the photographed area to provide scale and mark plot corners to facilitate photo analysis. The LLAPS was typically centered 60-70 $\mathrm{m}$ above the center of the targeted area.

Photo Selection and Analysis. Series of images for each plot were downloaded from the digital camera to a desktop computer in the lab. A trained technician (Kansas Cooperative Fish and Wildlife Research Unit) then selected a single photograph for each plot for each year to be analyzed. The single photograph used for each plot in a given year was chosen for overall clarity of the image, visibility of corner markers, and positioning of the plot in the photograph. After georeferencing

Table 2. Slope and intercept estimates for linear and quadratic trends in recovery of aboveground vegetation biomass following M1A1 tank disturbance. ${ }^{1}$

\begin{tabular}{|c|c|c|c|c|c|c|}
\hline \multirow[b]{3}{*}{ Effect (treatment $\times$ area) ${ }^{2}$} & \multicolumn{6}{|c|}{ Estimate } \\
\hline & \multicolumn{3}{|c|}{ Silty clay loam soil } & \multicolumn{3}{|c|}{ Silt loam soil } \\
\hline & Grass & Forb & Total & Grass & Forb & Total \\
\hline Dry curve & -114.9 & 4.9 & -99.0 & -102.8 & -21.9 & -87.4 \\
\hline Dry straightaway & -114.2 & -88.7 & -82.9 & -92.2 & -125.3 & -92.8 \\
\hline Wet curve & -113.4 & -105.8 & -114.1 & -98.5 & -142.0 & -94.4 \\
\hline Wet straightaway & -108.0 & -162.7 & -106.4 & -94.9 & -182.7 & -91.9 \\
\hline \multirow[t]{2}{*}{ Common linear slope } & $27.7^{3}$ & 74.2 & 47.7 & 31.6 & 59.4 & 27.4 \\
\hline & $43.9^{4}$ & & & & & \\
\hline Common quadratic slope & NS & NS & -6.2 & NS & NS & NS \\
\hline$r^{2}$ & 0.84 & 0.60 & 0.86 & 0.96 & 0.53 & 0.88 \\
\hline
\end{tabular}

${ }^{1}$ Based on a disturbance response calculated as (disturbed biomass - undisturbed biomass)/undisturbed biomass.

${ }^{2}$ Treatment indicates tank traffic during wet vs. dry soil conditions; area, subplot from which sample was collected (curve vs. straightaway). NS indicates not significant.

${ }^{3}$ Common slope estimate for curve area.

${ }^{4}$ Common slope estimate for straightaway area. 

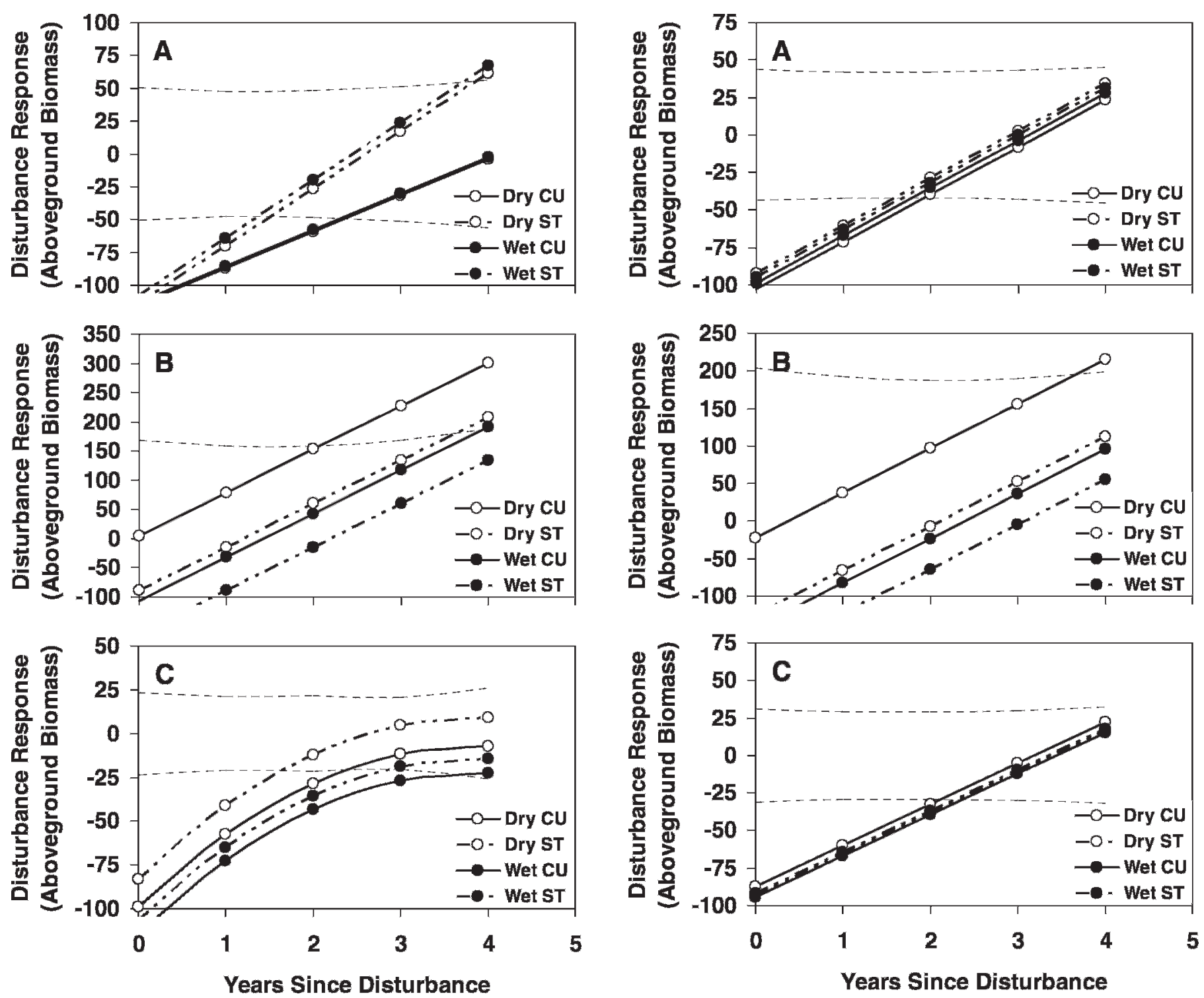

Figure 2. Recovery trends for aboveground biomass of $\mathbf{A}$, grasses, $\mathbf{B}$, forbs, and C, total vegetation on curves (CU) and straightaway (ST) areas of Abrams M1A1 main battle tank tracks created during wet and dry soil conditions in a silty clay loam soil. Recovery rate differed $(P=0.04)$ between areas for grasses (see Table 1). Slopes and intercepts for regression models are shown in Table 2. Horizontal dashed lines represent upper and lower 95\% confidence limits for $H_{0}$ : estimate $=0$. Disturbance response calculated as (disturbed measurement - undisturbed measurement)/undisturbed measurement; aboveground biomass in control plots averaged 97.2 and $77.1 \mathrm{~g} \cdot \mathrm{m}^{-2}$ for grasses and forbs, respectively, in the silty clay loam soil.

using global positioning system (GPS) coordinates obtained with a Trimble GeoXT (GeoExplorer, Ltd., Sophia, Bulgaria) handheld unit, photographs were then loaded in ArcMap (ESRI, Redlands, CA) as a raster layer. Using the editor tool within ArcMap, the technician traced polygons around the visible bare-ground areas in each plot, constructing a separate layer for all patches of bare ground $\geq 1 \mathrm{~m}^{2}$. HAWTHS tools (Beyer 2004) was used to calculate the area $\left(\mathrm{m}^{2}\right)$ of bare ground for each plot. Percentage of bare ground in each plot was calculated by dividing the area of bare ground by the total area

Figure 3. Recovery trends for aboveground biomass of $\mathbf{A}$, grasses, $\mathbf{B}$, forbs, and $\mathbf{C}$, total vegetation on curves (CU) and straightaway (ST) areas of Abrams M1A1 main battle tank tracks created during wet and dry soil conditions in a silt loam soil. Recovery was not affected by moisture condition or area (see Table 1). Slopes and intercepts for regression models are shown in Table 2 . Horizontal dashed lines represent upper and lower $95 \%$ confidence limits for $H_{0}$ : estimate $=0$. Disturbance response calculated as (disturbed measurement - undisturbed measurement)/undisturbed measurement; aboveground biomass in control plots averaged 218.5 and $64.9 \mathrm{~g} \cdot \mathrm{m}^{-2}$ for grasses and forbs, respectively, in the silt loam soil.

in a $35 \times 70 \mathrm{~m}\left(\sim 2450 \mathrm{~m}^{2}\right)$ plot arbitrarily placed to contain the impacted area in each figure-eight treatment.

\section{Statistical Analyses}

A disturbance effect index was calculated for all variables using the following formula:

(disturbed measurement - undisturbed measurement)/ undisturbed measurement. 
This disturbance effect index was expressed as a percentage of the control and subjected to mixed-model analysis of variance with the use of SAS (SAS Institute Inc. 2004). The data were analyzed as a split-split plot with correlated subplots (5 passes vs. 10 passes) and correlated sub-subplots (curve vs. straight areas) with each subplot using a repeated-measures analysis of variance modeling time (i.e., year) as a regression variable. Models were constructed according to Littell et al. (1996) with the use of SAS PROC MIXED. Linear and quadratic effects were tested and, where quadratic effects were not significant, a linear model was fit to the data. Slopes were compared among experimental treatments, and an equal slope model was fit where appropriate (i.e., where slopes did not vary among treatments). The significance of model estimates (based on deviation from undisturbed plots) were tested with the use of least-squares means $\left(H_{0}\right.$ : estimate $\left.=0\right)$. Because the fire treatment was not implemented until 2006, burning was not included in the regression analyses, but significant burning effects on undisturbed control plots were incorporated into the disturbance index. Principal-components analysis (PCA) was used to analyze disturbance-related patterns in plant community composition.

\section{RESULTS}

\section{Weather Patterns}

Monthly averages, as well as long-term patterns in precipitation and evapotranspiration, are presented in Figure 1. Spring months, especially April and May, generally were drier than average throughout the present study, whereas summer months, particularly August, were wetter than average. Evapotranspiration values in all years were typical of longterm averages.

\section{Aboveground Biomass}

Aboveground biomass in control plots averaged 97.2 and $218.5 \mathrm{~g} \mathrm{~m}^{-2}$ for grasses in silty clay loam soil and silt loam soil, respectively, across years. Aboveground forb biomass in control plots averaged 77.1 and $64.9 \mathrm{~g} \cdot \mathrm{m}^{-2}$ in silty clay loam soil and silt loam soil, respectively. Burning effects on aboveground biomass, when significant $(P \leq 0.05)$, varied with year. Grass biomass in burned control plots in silty clay loam soil averaged $250 \%$ of unburned plots for the burn year (2006) but only $55 \%$ of unburned plots for the following year. No differences in biomass due to burning were observed for grasses in silt loam soil or for forbs in either soil.

Recovery of aboveground biomass following M1A1 tank disturbance in the silty clay loam soil varied with area of track sampled (i.e., curve vs. straightaway) and, marginally, with initial soil moisture condition, but not with traffic intensity (Table 1). Recovery in the silt loam soil did not vary with moisture condition, area, or traffic intensity. Linear and quadratic trends over time generally were consistent across treatments, sampling areas, and traffic intensities permitting regression models to be fit with common slopes.

The disturbance response of aboveground biomass for grasses displayed a linear trend over time in both silty clay loam and silt loam soils (Tables 1 and 2; Figs. 2 and 3). The rate of recovery (i.e., slope) was consistent across treatments and sampling areas
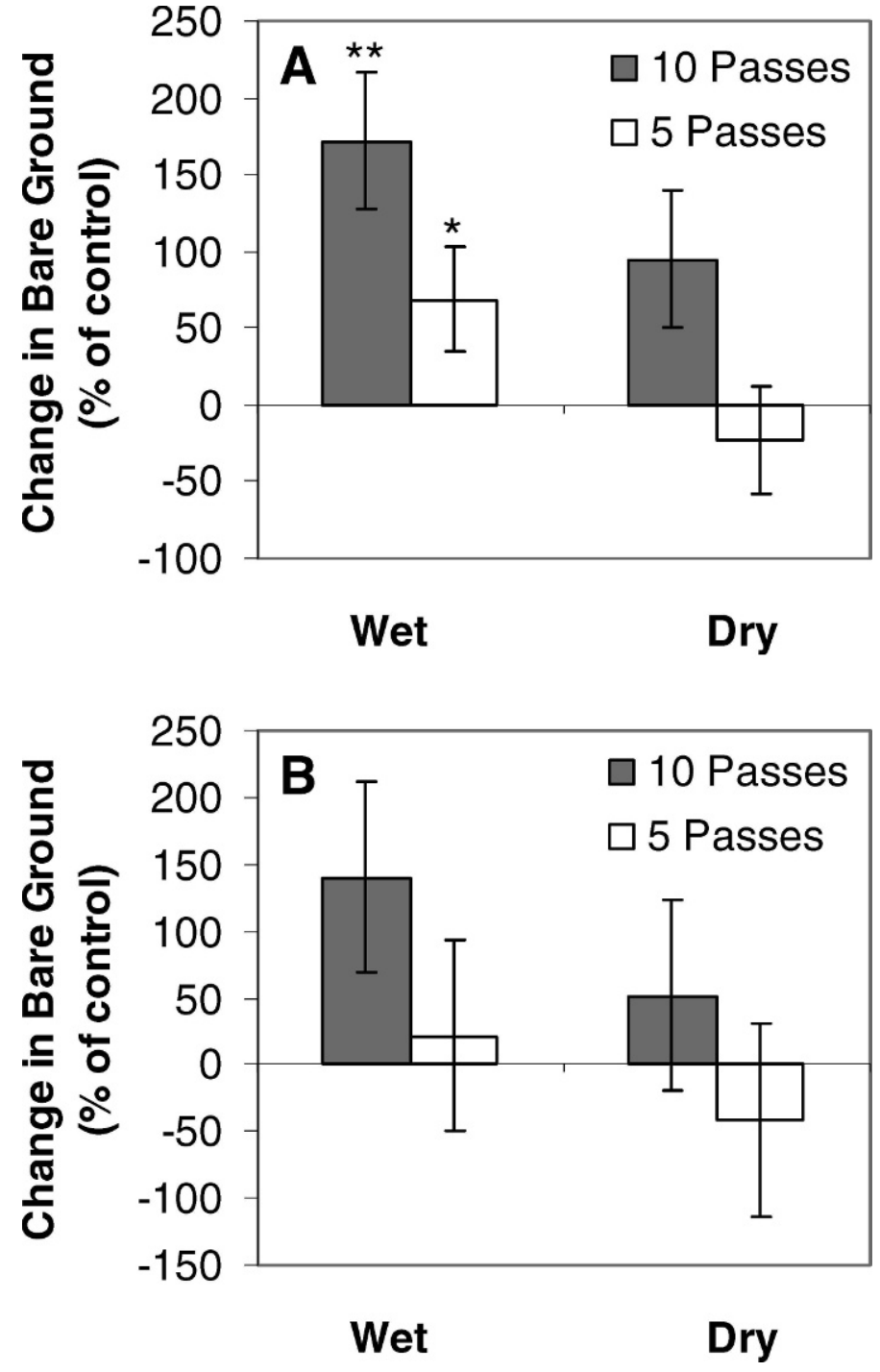

Figure 4. Disturbance response for bare ground in A, silty clay loam soil, and $\mathbf{B}$, silt loam soil, 2007. Disturbance treatments consisted of 5 passes (2003) or 10 passes ( 5 additional passes on one-half of the plot in 2004) with an Abrams M1A1 main battle tank during wet and dry soil conditions. Data are means \pm standard error. * ${ }^{*}{ }^{*}$ indicate $P \leq 0.05$, 0.01 , respectively. Bare ground averaged $38 \%$ and $16 \%$ for burned and unburned controls, respectively, in silty clay loam soil, and $24 \%$ and $8 \%$ for burned and unburned controls, respectively, in silt loam soil.

in silt loam soil, but was more $\operatorname{rapid}(P=0.04)$ on straightaways compared to curve areas in silty clay loam soil, with recovery on curve areas delayed by a full growing season (Fig. 2A). Recovery of grasses did not vary with any treatment in the silt loam soil (Table 1; Fig. 4A). Regression models predicted that recovery of aboveground biomass required a minimum of 2-3 yr for grasses in both soil types.

Aboveground biomass for forbs also showed significant linear trends over time, with regression models predicting rapid increases in biomass relative to undisturbed control plots in both soil types (Tables 1 and 2; Figs. 3 and 4). Forb biomass in silty clay loam soil increased on curve areas and in the drytrafficked straightaway to levels greater than $(P \leq 0.05)$ those of undisturbed plots within 3-4 yr following disturbance (Fig. 2B). In silt loam soil, forb biomass was stimulated 
Table 3. Principal-components analysis of vegetation taxa for the silty clay loam and silt loam soils, 2005 and 2007.

\begin{tabular}{|c|c|c|c|c|c|c|c|c|}
\hline \multirow[b]{4}{*}{ Plant taxa } & \multicolumn{8}{|c|}{ Eigenvectors } \\
\hline & \multicolumn{4}{|c|}{ Silty clay loam } & \multicolumn{4}{|c|}{ Silt loam } \\
\hline & \multicolumn{2}{|c|}{2005} & \multicolumn{2}{|c|}{2007} & \multicolumn{2}{|c|}{2005} & \multicolumn{2}{|c|}{2007} \\
\hline & $P C^{1} 1$ & PC 2 & PC 1 & PC 2 & PC 1 & PC 2 & PC 1 & PC 2 \\
\hline \multicolumn{9}{|l|}{ Big bluestem } \\
\hline (Andropogon gerardii) & -0.30 & 0.27 & -0.08 & -0.30 & 0.12 & 0.00 & 0.25 & -0.33 \\
\hline \multicolumn{9}{|l|}{ Little bluestem } \\
\hline (Schizachyrium scoparium) & 0.14 & 0.36 & 0.10 & 0.03 & 0.16 & 0.50 & 0.40 & 0.21 \\
\hline \multicolumn{9}{|l|}{ Switchgrass } \\
\hline (Panicum virgatum) & -0.02 & -0.02 & 0.33 & -0.22 & 0.35 & 0.02 & -0.01 & -0.04 \\
\hline \multicolumn{9}{|l|}{ Indiangrass } \\
\hline (Sorghastrum nutans) & 0.42 & -0.13 & 0.29 & 0.46 & 0.49 & 0.05 & -0.20 & -0.13 \\
\hline \multicolumn{9}{|l|}{ Dropseed } \\
\hline (Sporobolus asper) & 0.09 & -0.43 & -0.16 & -0.27 & 0.23 & -0.24 & -0.16 & 0.25 \\
\hline Brome (Bromus spp.) & -0.15 & -0.32 & -0.20 & -0.10 & -0.13 & 0.33 & -0.29 & 0.44 \\
\hline \multicolumn{9}{|l|}{ Prairie junegrass } \\
\hline (Koeleria macrantha) & 0.40 & 0.08 & 0.06 & 0.52 & -0.08 & 0.25 & 0.43 & 0.28 \\
\hline Sedge (Carex spp.) & 0.12 & 0.24 & 0.15 & -0.12 & 0.25 & -0.27 & 0.36 & -0.20 \\
\hline Other grasses & -0.29 & 0.19 & -0.31 & -0.04 & -0.13 & -0.28 & -0.21 & -0.50 \\
\hline \multicolumn{9}{|l|}{ Heath aster } \\
\hline (Aster ericoides) & 0.23 & -0.11 & 0.38 & 0.00 & 0.27 & 0.30 & 0.11 & 0.04 \\
\hline \multicolumn{9}{|l|}{ Illinois bundleflower } \\
\hline (Desmanthus illinoensis) & -0.38 & -0.14 & 0.12 & -0.28 & 0.36 & 0.12 & 0.00 & 0.00 \\
\hline \multicolumn{9}{|l|}{ Ragweed } \\
\hline (Ambrosia spp.) & -0.13 & -0.20 & -0.27 & -0.01 & -0.22 & 0.25 & -0.08 & 0.09 \\
\hline \multicolumn{9}{|l|}{ Goldenrod } \\
\hline (Solidago spp.) & 0.31 & -0.05 & 0.36 & 0.03 & -0.01 & 0.45 & 0.40 & 0.25 \\
\hline \multicolumn{9}{|l|}{ Daisy fleabane } \\
\hline (Erigeron strigosus) & -0.09 & 0.51 & -0.23 & 0.43 & -0.27 & 0.04 & -0.29 & 0.36 \\
\hline Other forbs & -0.32 & -0.24 & -0.42 & 0.13 & -0.34 & 0.04 & -0.11 & 0.10 \\
\hline Eigenvalue & 3.57 & 2.88 & 3.00 & 2.09 & 3.40 & 2.60 & 2.81 & 2.13 \\
\hline Cumulative variance (\%) & 23.81 & 42.99 & 19.98 & 33.89 & 22.69 & 39.99 & 20.06 & 35.30 \\
\hline
\end{tabular}

${ }^{1} \mathrm{PC}$ indicates principal component.

similarly on curve areas following disturbance during dry soil conditions (Fig. 3B). Rates of recovery were consistent across treatments and sampling areas in both soil types, and recovery did not vary among treatments.

Trends in recovery of total aboveground biomass following disturbance were similar to those of grasses, reflecting the dominance of this group, but with significant $(P \leq 0.05)$ quadratic as well as linear effects observed for the silty clay loam soil (Tables 1 and 2; Figs. 2 and 3). Regression models predicted marginally greater $(P=0.09)$ levels of biomass following disturbance during dry compared to wet soil conditions for the silty clay loam soil (Tables 1 and 2; Fig. 2C). No differences in recovery were detected among treatments in silt loam soil (Tables 1 and 2; Fig. 3C).

\section{Aerial Image and Step-Point Analysis of Cover}

Visible bare ground in aerial images of M1A1 figure- 8 tracks decreased from a May 2004 (1 yr after initial disturbance) average of $337 \mathrm{~m}^{2}$ and $45 \mathrm{~m}^{2}$ for silty clay loam and silt loam soil, respectively, to a June 2007 average of $11 \mathrm{~m}^{2}$ and $1 \mathrm{~m}^{2}$, respectively. This represented a 97-98\% decrease in bare ground (and a corresponding recovery in vegetative cover) in both soil types during a 3-yr period. No effects due to soil moisture at the time of treatment were discernible for either the amount of bare ground or recovery.

Step-point analysis indicated that tank tracks in the silty clay loam soil continued to exhibit significantly $(P \leq 0.05)$ more bare ground than undisturbed control plots at the end of the study in 2007, but only following disturbance during wet moisture conditions (Fig. 4A). The percentage of bare ground was marginally greater $(P=0.08)$ for repeated than for single traffic events. A similar pattern was observed for the silt loam soil, with only repeated traffic during wet soil conditions continuing to display $(P=0.06)$ more bare ground than control plots (Fig. 4B).

\section{Community Analysis}

The first two principal components from a PCA of vegetation community structure in 2005 and 2007 are shown in Table 3. These components explained $34-43 \%$ of the total variation in 

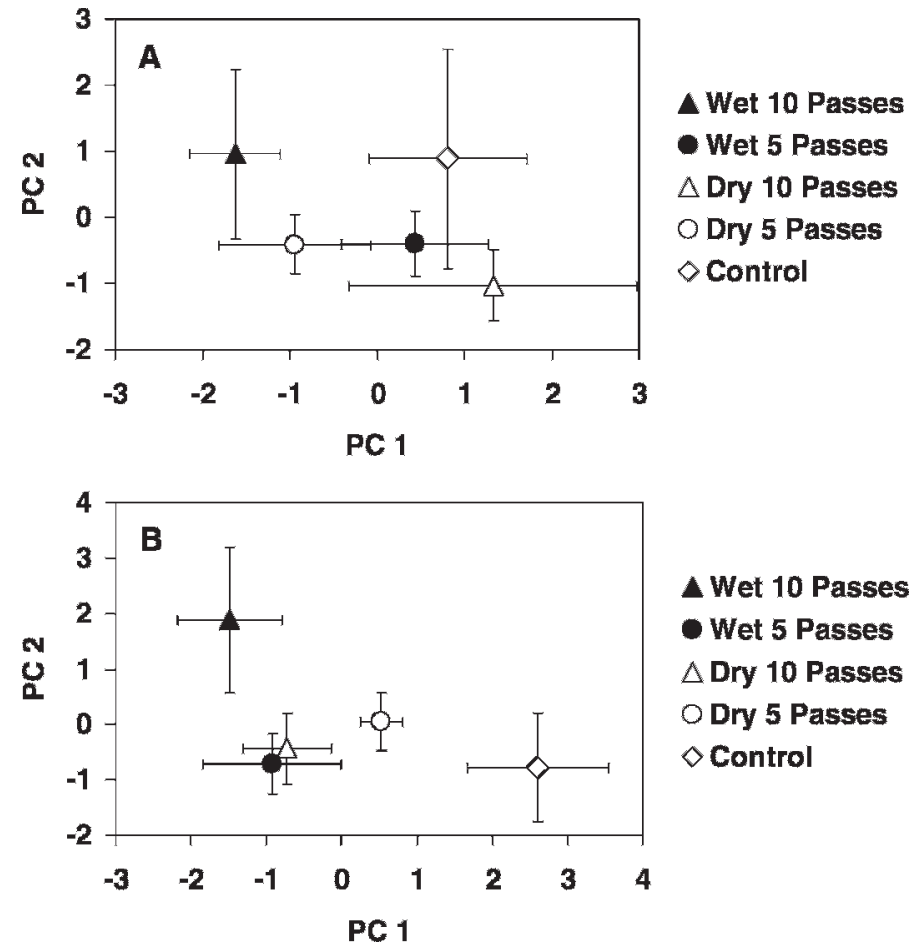

Figure 5. Scatterplot of first and second principal components (PC 1 and PC 2) for major vegetation taxa (see Table 3) in $\mathbf{A}$, silty clay loam soil, and B, silt loam soil, 2005. Disturbance treatments consisted of 5 passes (2003) or 10 passes ( 5 additional passes on one-half of the plot in 2004) with an Abrams M1A1 main battle tank during wet and dry soil conditions. Data are means \pm standard errors.

the data set. Separation of individual treatments primarily occurred on the first principal component, with repeated traffic under wet soil conditions consistently exhibiting the most negative values among all treatments, whereas control plots exhibited positive values (Figs. 5 and 6). The weightings for individual plant taxa were similar across soil types and years for this component (Table 3), which can loosely be interpreted as a contrast of the positively weighted relative abundance of typically dominant prairie grasses and forbs (e.g., switchgrass, indiangrass, prairie junegrass, and/or goldenrod) vs. the negatively weighted relative abundance of normally subdominant grasses and forbs (e.g., brome and daisy fleabane).

\section{DISCUSSION}

Destruction of vegetation is one of the primary impacts of tracked vehicle maneuvers and can result in significant secondary effects such as soil loss through erosion (Grantham et al. 2001). From this perspective, ground cover is a key indicator of ecosystem health, and revegetation of disturbed areas is an essential first step in the recovery process. Grasslands are considered to be relatively resilient compared to other military training lands (Yorks et al. 1997), but prairie plant species show differential responses to disturbance, often resulting in significant shifts in species composition even in the absence of measurable effects on plant biomass (Schaeffer et al. 1990; Hartnett and Fay 1998). In this study, perennial warm- season grasses were largely replaced by annual cool-season grasses and forbs during the recovery process, a pattern also observed following military tracked-vehicle maneuvers in Colorado grasslands (Shaw and Diersing 1990; Milchunas et al. 1999). Invasive exotic species are an additional concern following tank traffic in grassland ecosystems (Wilson 1988; Milchunas et al. 1999; Althoff et al. 2006).

Althoff (2005) reported that vegetative biomass remained severely impacted $(45-49 \%$ lower in disturbed areas compared to undisturbed controls) across two soil types (silty clay loam and silt loam soils) $1 \mathrm{yr}$ following tank maneuvers, with recovery patterns of grasses and forbs varying with soil moisture condition at the time of disturbance. Greater soil moisture at the time of trafficking has been observed to magnify the negative impacts of training on vegetation (Yorks et al. 1997) and this was confirmed in this study. Patterns of recovery subsequent to those reported by Althoff (2005) indicate that reductions in biomass (current year's biomass) continued for at least $3 \mathrm{yr}$ in areas with the greatest disturbance (i.e., curves, wet soil conditions). The relative abundance of plant species was a better indicator of disturbance and recovery for both grasses and forbs, with dominant species (e.g., A. gerardii and $D$. illinoensis) replaced by subdominant species (e.g., K. macrantha and Solidago spp.).

The effects of traffic intensity (5 vs. 10 passes) on plant biomass and cover were still detectable in 2007, 3-4 yr after disturbance. Because traffic-intensity effects are confounded with years since disturbance in the present study, it is difficult to attribute how much of this effect is in fact due to intensity. Traffic intensity did differentially impact range grasses at the Yakima Training Center in Washington (Palazzo et al. 2005) and in an independent study at Fort Riley (Dickson et al. 2008), with relative abundance of desirable species declining with increasing traffic intensity. Similarly, species composition and the percent bare ground were found to vary with traffic frequency in a mixed-grass prairie, with both higher frequencies of bare ground and shifts in plant species composition observed when traffic capacity was exceeded (Wilson 1988). In contrast, moderate and heavy use by tracked vehicles increased bare ground but did not affect plant species composition in transitional grassland in North Dakota (Prosser et al. 2000). Even when there are differences due to traffic intensity, it is important to note that the greatest losses to vegetation occur with the first few passes (Yorks et al. 1997; Althoff 2005).

In addition to intensity, turning during vehicle maneuvers had a residual effect on vegetation recovery, with only curvearea vegetation displaying significant disturbance at the end of the study (year 4). Ayers (1994) reported that sharper turns by tracked vehicles produced more severe vegetation damage, but this pattern was not observed early in the present study (year 1 ), where reductions in vegetation biomass were equivalent between curve and straightaway areas. Soil surface disturbance, however, was noticeably more severe for curve areas compared to straightaways, and the displacement of topsoil and associated rutting (see Althoff 2007) appears to have reduced the seed/rhizome bank and limited vegetative recovery in these areas.

Fire interacts with other disturbances to alter plant community structure in the tallgrass prairie (Collins and Gibson 1990). Burning also represents an effective tool for land managers 


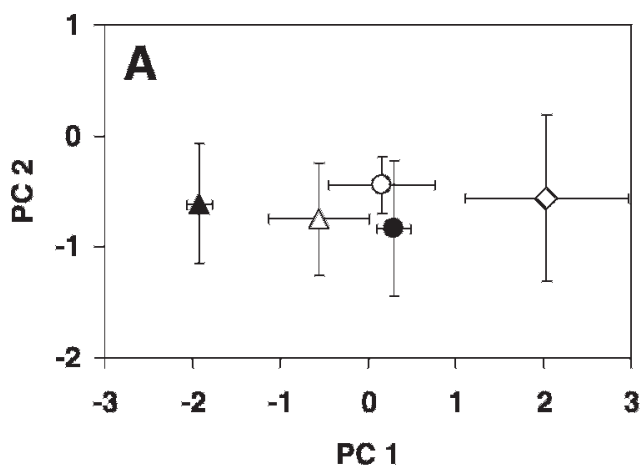

$\Delta$ Wet 10 Passes

- Wet 5 Passes

$\triangle$ Dry 10 Passes

0 Dry 5 Passes

$\diamond$ Control

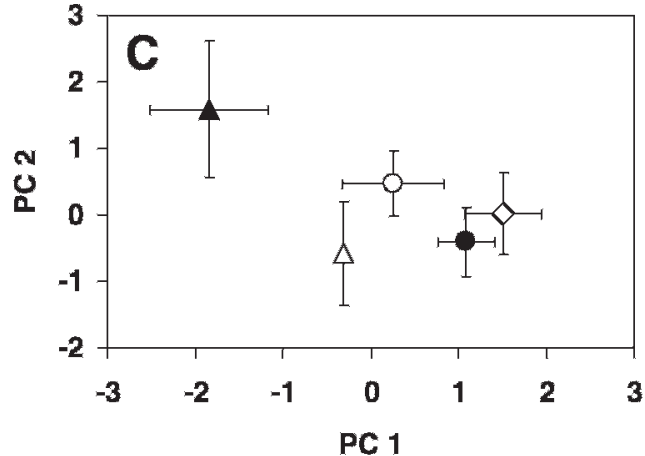

$\Delta$ Wet 10 Passes

- Wet 5 Passes

$\triangle$ Dry 10 Passes

O Dry 5 Passes

$\diamond$ Contral
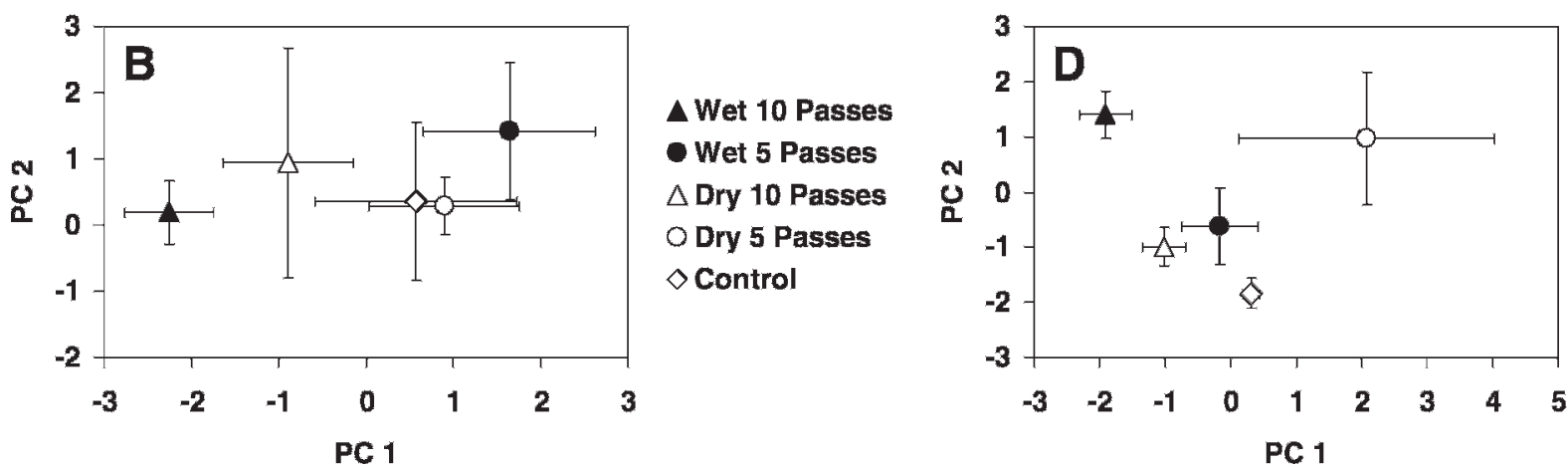

$\Delta$ Wet 10 Passes

$\Delta$ Wet 10 Passes

- Wet 5 Passes

$\triangle$ Dry 10 Passes

O Dry 5 Passes

$\diamond$ Control

Figure 6. Scatterplot of first and second principal components (PC 1 and PC 2) for major vegetation taxa (see Table 3) in A, burned silty clay loam soil, B, unburned silty clay loam soil, C, burned silt loam soil, and D, unburned silt loam soil, 2007. Disturbance treatments consisted of 5 passes (2003) or 10 passes (5 additional passes on one-half of the plot in 2004) with an Abrams M1A1 main battle tank during wet and dry soil conditions. Data are means \pm standard errors.

(Wright 1974). In mesic grasslands such as the tallgrass prairie, burning typically enhances production of the dominant $\mathrm{C}_{4}$ grasses and increases nitrogen limitation, allowing warmseason grasses to outcompete forbs (Knapp and Seastedt 1986; Seastedt et al. 1991). Therefore, burning would be expected to enhance the recovery of native warm-season grasses following disturbance by tracked vehicles. In the present study, fire effects were observed for vegetation in undisturbed control plots, but there was little evidence that burning influenced its subsequent recovery in trafficked areas, likely because of fuel (i.e., litter) limitations within the tank tracks. Nonetheless, the known ability of fire to enhance production and regulate species composition in tallgrass prairie warrants its use as a management tool once adequate fuel levels are attained.

Aerial image analysis indicated nearly total aboveground recovery of vegetation in tank tracks after 4 yr. Although lowlevel aerial photography for bare-ground analysis is not capable of assessing basal cover, the bare-ground estimates obtained with aerial photography generally were supported by step-point estimates of bare ground in the sense that both showed substantial recovery of vegetative cover during the study. Vegetative cover is important for controlling erosion resulting from raindrop impact. Image analysis for measuring ground cover has been noted for its capabilities to assess large numbers of samples, reduce biases possibly induced by human subjectivity, and leave researchers in the future with a permanent data record (Booth et al. 2005). Aerial image analyses for quantification of vegetative cover have been conducted with an extremity of sampling scales ranging from heights of $2 \mathrm{~m}$ to $100 \mathrm{~m}$ (Bennett et al. 2000; Booth et al. 2003).

Data resulting from the aerial analysis of bare ground for each plot should be interpreted with caution, however. Many improvements in field protocols were made as the study progressed. The importance of positioning the photography system directly over the center of the plot must be stressed. Using the camera-tilting feature of the aerial photography system creates distortion in the image, thus leading to problems with processing steps, such as georeferencing, in the laboratory. If images are not accurately georeferenced, bare ground will not be accurately represented. Other problems existed in the early onset of this aerial photography system, and therefore year-to-year comparisons could not be dependably made. These problems involved the switching of camera gear to a higher-resolution camera in 2007, the incorrect placement of highly visible white markers prior to taking a photograph, and the suspicion that permanent plot markers may have been slightly moved by uncontrolled military training events.

Ground-based methods, such as the step-point technique, complement aerial image analysis, and are necessary to evaluate fully the recovery status of the plant community. By the end of the present study, for instance, plant community structure remained significantly altered, even though vegetative cover and biomass displayed few residual disturbance effects. Although this may be sufficient for military training needs, it does not fulfill the requirements for sustainability originally outlined by the LCTA program (Diersing et al. 1992). 
Replacement of desirable tallgrass prairie plants with species that are less resilient will lengthen recovery periods, resulting in less-suitable lands for training.

Climate change models predict anything from declines to moderate increases in precipitation for the central Great Plains, with rainfall increases occurring in the form of less frequent but heavier rainfall events (Council for Agricultural Science and Technology 2004). Although long-term weather changes cannot be determined from this 5-yr study, the weather patterns observed during this study largely match these predictions. Spring precipitation, in particular, was frequently well below the long-term average, but there were months of extreme summer rainfall in three of the $5 \mathrm{yr}$. Fortunately, the tallgrass prairie, in addition to being relatively resilient to disturbance, is less sensitive to variations in precipitation than many ecosystems (Seastedt et al. 1998). Persistent drought, however, could reduce the abundance of the resilient tallgrass species, thus necessitating changes in military training practices.

\section{IMPLICATIONS}

The tallgrass prairie typically is considered to be among the most resilient of military training lands. Our study indicates that resiliency is dependent upon soil type and training conditions, and may require longer periods of recovery than previously thought. Dominant tallgrass species, in particular, failed to recover completely within the 4-yr time period covered by this study. As resiliency of this system is largely dependent upon native warm-season grasses, their lack of recovery has significant implications for long-term sustainability under conditions of training with Abrams M1A1 main battle tanks. The recovery models developed in this study provide a basis for developing guidelines for assessing training conditions and management of vehicle impact on military lands in grassland ecosystems.

\section{ACKNOWLEDGMENTS}

Funding for this project was provided by the US Army Military Installation, ITAM Program. The authors thank Philip B. Woodford (ITAM), Coordinator; Chris Otto (ITAM); Lee Breidenstein (Range Control); Tony Davis; Troy Livingston (GPS); Monte Cales (Natural Resources Conservation Service [NRCS]); Fred Siebe and staff (Multi-Purpose Range Complex Gunnery Complex); and M1A1 tank crews from Fort Riley Military Installation for their effort and support. We are indebted to Dr Carol Blocksome, Dr Walter Fick, Dr Clenton Owensby, Rebecca Lyons (NRCS, Manhattan), and Alex Miller (NRCS, Westmoreland), for assistance in step-point analysis, including collecting and identifying the plant species. Finally, we express appreciation to Dr Donald Althoff, Kevin Blecha, and staff (US Geographical Survey, Kansas Cooperative Fish and Wildlife Research Unit) for their assistance in collecting blimp images and data, and Dr Mary Knapp (State Climatologist, Weather Data Library), Jamey Duesterhaus, and Stephen Arnold for weather data contributions.

\section{LITERATURE CITED}

ALthoff, P. S. 2005. Evaluation of soil quality indicators following disturbance by an Abrams M1A1 main battle tank [thesis]. Manhattan, KS, USA: Kansas State University. 136 p.
Althoff, P. S. 2007. Indicators of disturbance and recovery of a tallgrass prairie ecosystem following military vehicle traffic [dissertation]. Manhattan, KS, USA: Kansas State University. 230 p.

Althoff, D. P., P. S. Althoff, N. D. Lambrecht, P. S. Gipson, J. S. Pontius, and P. B. WoOdFORD. 2007. Soil properties and perceived disturbance of grasslands subjected to mechanized military training: evaluation of an index. Land Degradation and Development 18:269-288.

Althoff, D. P., P. S. Gipson, J. S. Pontius, and P. B. Woodford. 2006. Plant community and bare ground trends on Fort Riley, Kansas: implications for monitoring of a highly disturbed landscape. Transactions of the Kansas Academy of Science 109:101-106.

Althoff, P. S., AND S. J. Thien. 2005. Impact of M1A1 main battle tank disturbance on soil quality, invertebrates, and vegetation characteristics. Journal of Terramechanics 42:159-176.

Anderson, A. B., A. J. Palazzo, P. D. Ayers, J. S. Fehmi, S. Shoop, and P. Sullivan. 2005a. Assessing the impacts of military vehicle traffic on natural areas. Introduction to the special issue and review of the relevant military vehicle impact literature. Journal of Terramechanics 42:143-158.

Anderson, A. B., G. Wang, S. Fang, G. Z. Gertner, B. Guneralp, and D. Jones. 2005b. Assessing and predicting changes in vegetation cover associated with military land use activities using field monitoring data at Fort Hood, Texas. Journal of Terramechanics 42:207-229.

Army Regulation 350-4. 1988. Integrated Training Area Management (ITAM). Unclassified. Washington, DC, USA: Headquarters Department of the Army.

AYERS, P. 1994. Environmental damage from tracked vehicle operation. Journal of Terramechanics 31:173-183.

Bennett, L. T., T. S. Judd, And M. A. Adams. 2000. Close-range vertical photography for measuring cover changes in perennial grassland. Journal of Range Management 53:634-641.

BEYER, H. L. 2004. Hawth's analysis tools for ArcGIS. Available at: http://www. spatialecology.com/htools. Accessed 18 August 2009.

Booth, D. T., S. E. Cox, C. Fifield, M. Phillips, and N. Williamson. 2005. Image analysis compared with other methods for measuring ground cover. Arid Land Research and Management 19:91-100.

Booth, D. T., D. Glenn, B. Keating, J. Nance, S. E. Cox, and J. Barrier. 2003. Monitoring rangeland watersheds with very-large scale aerial imagery. In: Proceedings of the first interagency conference on research in the watersheds; 27-30 October 2003; Benson, AZ, USA. Washington, DC, USA: US Department of Agriculture, Agricultural Research Service. p. 212-215.

Collins, S. L., And D. J. GiBson. 1990. Effects of fire on community structure in tallgrass and mixed-grass prairie. In: S. L. Collins and L. L. Wallace [EDS.]. Fire in North American tallgrass prairies. Norman, OK, USA: University of Oklahoma Press, Publishing Division. p. 81-98.

Council for Agricultural Science and Technology. 2004. Climate change and greenhouse gas mitigation: challenges and opportunities for agriculture. Task Force Report no. 141. Ames, IA, USA: Council for Agricultural Science and Technology. 120 p.

Dickson, T. L., B. J. Wilsey, R. R. Busby, and D. L. GebHart. 2008. Grassland plant composition alters vehicular disturbance effects in Kansas, USA. Environmental Management 41:676-684.

Diersing, V. E., R. B ShaW, and D. J. TaziK. 1992. US Army Land Condition-Trend Analysis (LCTA) program. Environmental Management 16:405-414.

Engle, D. M., And T. G. Bidwell. 2001. The response of central North American prairies to seasonal fire. Journal of Range Management 54:2-10.

Evans, R. A., And R. M. Love. 1957. The step-point method of sampling-a practical tool in range research. Journal of Range Management 10:208212.

Grantham, W. P., E. F. Redente, C. F. Bagley, and M. W. Paschke. 2001. Tracked vehicle impacts to vegetation structure and soil erodibility. Journal of Range Management 54:711-716.

Gunderson, L. H. 2000. Ecological resilience-in theory and application. Annual Review of Ecological Systems 31:425-439.

Hartnett, D. C., and P. A. Fay. 1998. Plant populations: patterns and process. In: A. K. Knapp, J. M. Briggs, D. C. Hartnet, and S. L. Collins [EDs.]. Grassland 
dynamics: long-term ecological research in tallgrass prairie. New York, NY, USA: Oxford University Press. p. 81-100.

HaYden, B. P. 1998. Regional climate and the distribution of tallgrass prairies. In: A. K. Knapp, J. M. Briggs, D. C. Hartnett, and S. L. Collins [EDs.]. Grassland dynamics: long-term ecological research in tallgrass prairie. New York, NY, USA: Oxford University Press. p. 19-34.

Holııng, C. S. 1973. Resilience and stability of ecological systems. Annual Review of Ecological Systems 4:1-23.

KNAPP, A. K., AND T. R. SEAStedt. 1986. Detritus accumulation limits productivity of tallgrass prairie. Bioscience 36:662-668.

Knapp, A. K., and T. R. Seastedt. 1998. Grasslands, Konza Prairie, and long-term ecological research. In: A. K. Knapp, J. M. Briggs, D. C. Hartnet, and S. L. Collins [EDS.]. Grassland dynamics: long-term ecological research in tallgrass prairie. New York, NY, USA: Oxford University Press. p. 3-15.

Littell, R. C., G. A. Milliken, W. W. Stroup, and R. D. Wolfinger. 1996. SAS system for mixed models. Cary, NC, USA: SAS Institute. 633 p.

Milchunas, D. G., K. A. Schulz, and R. B. Shaw. 1999. Plant community responses to disturbance by mechanized military maneuvers. Journal of Environmental Quality 28:1533-1547.

Palazzo, A. J., K. B. Jensen, B. L. Waldron, and T. J. Cary. 2005. Effect of tank tracking on range grasses. Journal of Terramechanics 42:177-191.

Prosser, C. W., K. K. Sedivec, and W. T. Barker. 2000. Tracked vehicle effects on vegetation and soil characteristics. Journal of Range Management 53:666-670.

Quist, M. C., P. A. Fay, C. S. Guy, A. K. Knapp, and B. N. Rubenstein. 2003. Military training effects on terrestrial and aquatic communities on a grassland military installation. Ecological Applications 13:432-442.

SAS InstituTE Inc. 2004. SAS/STAT user's guide. Version 9.1. Cary, NC, USA: SAS Institute Inc. 5136 p.
Schaeffer, D. J., T. R. Seastedt, D. J. Gibson, D. C. Hartnett, S. W. James, D. W. Kaufman, A. P. Schwab, E. E. Herricks, and E. W. Novak. 1990. Field bioassessments for selecting test systems to evaluate military training lands in tallgrass prairie. Ecosystem Health $v$. Environmental Management 14:81-93.

SeAstedt, T. R., J. M. Briggs, and D. J. Gipson. 1991. Controls of nitrogen limitation in tallgrass prairie. Oecologia 87:72-79.

Seastedt, T. R., B. P. Hayden, C. E. Owensby, and A. K. Knapp. 1998. Climate change, elevated $\mathrm{CO}_{2}$ and predictive modeling: past and future climate change scenarios for the tallgrass prairie. In: A. K. Knapp, J. M. Briggs, D. C. Hartnett, and S. L. Collins [EDS.]. Grassland dynamics: long-term ecological research in tallgrass prairie. New York, NY, USA: Oxford University Press. p. 283300.

Shaw, R. B., and V. E. Diersing. 1990. Tracked vehicle impacts on vegetation at the Pinyon Canyon Maneuver Site, Colorado. Journal of Environmental Quality 19:234-243.

US Army Environmental Center. 2006. Sustainable range program: range and training land assessment program. Available at: http://aec.army.mil/usaec/ range/sustainment00.html. Accessed 18 August 2009.

uSDA, Soll Conservation Service in Cooperation with Kansas Agricultural Experiment Station. 1975. Soil survey of Riley and part of Geary County, Kansas.

WiLson, S. D. 1988. The effects of military tank traffic on prairie: a management model. Environmental Management 12:397-403.

WRIGHT, H. A. 1974. Range burning. Journal of Range Management 27:5-11.

Yorks, T. P., N. E. West, R. J. Mueller, and S. D. Warren. 1997. Toleration of traffic by vegetation: life form conclusions and summary extracts from a comprehensive data base. Environmental Management 21:121131. 